\title{
EFFECTS OF ORGANOMETALLIC CHELATES AND INULIN IN DIETS FOR LAYING HENS ON Mn AND Fe ABSORPTION COEFFICIENTS AND THEIR CONTENT IN EGG AND TISSUE
}

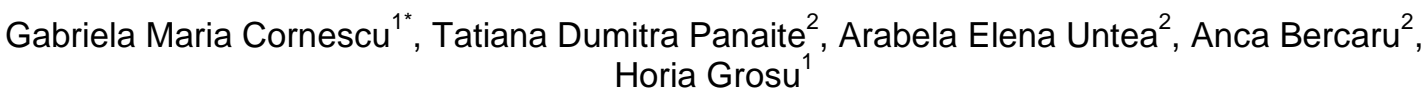 \\ ${ }^{1}$ Faculty of Animal Husbandry, University of Agricultural Sciences and Veterinary Medicine, 59 \\ Marasesti Boulevard, 011464 Bucuresti, Romania \\ ${ }^{2}$ National Institute of Research and Development for Animal Biology and Nutrition, 1 Calea Bucuresti, \\ 077015, Balotesti, Ilfov, Romania
}

\author{
*Corresponding author: \\ Phone: +40786906879 \\ Fax: +40213512080 \\ E-mail address: gabriela_cornescu@yahoo.com
}

\begin{abstract}
The aim of this study was to evaluate effects of organic sources of manganese $(\mathrm{Mn})$ and iron $(\mathrm{Fe})$ and inulin in diets for laying hens on absorption of these minerals and their deposition in egg and tissue. The study was conducted on 90 Lohmann Brown laying hens in the period from 46-52 weeks of age, assigned to 3 groups with 30 hens/group and 3 hens/cage. The hens from the control group $(\mathrm{C})$ received a diet based on corn, rice bran and soybean meal with $16 \%$ of crude protein, as well as $60 \mathrm{mg} \mathrm{Fe} / \mathrm{kg}$ and $71.9 \mathrm{mg} \mathrm{Mn} / \mathrm{kg}$ of diet in form of inorganic salts. The formulation of the experimental diets (E1 and E2) differed from $\mathrm{C}$ group diet by the replacement of inorganic $\mathrm{Fe}$ and $\mathrm{Mn}$ salts by organometallic chelates of these elements, at a level of $25 \%$ lower than in the premix for group C. As source of inulin, group E1 diet also included $0.5 \%$ of dry Jerusalem artichoke, while group E2 diet included $0.5 \%$ of a product based on chicory root extract. At the end of the experiment, 6 hens from each group were slaughtered and blood serum and liver samples were collected and assayed for concentration of $\mathrm{Fe}$ and $\mathrm{Mn}$. In the final week of the experiment, 18 eggs/group were collected for determination of $\mathrm{Fe}$ and $\mathrm{Mn}$ concentration in egg yolk. Concentration of measured blood serum parameters (haemoglobin, haematocrit, $\mathrm{Fe}$ and $\mathrm{Mn}$ ) in experimental $(\mathrm{E})$ groups were lower than in group $\mathrm{C}$, but no significant differences $(\mathrm{P}>0.05)$ were registered. Absorption coefficients of $\mathrm{Mn}$ had higher values in $E$ groups than in group $C$, with significant increase $(P<0.05)$ registered in group E2. Absorption coefficients of $\mathrm{Fe}$ had significantly lower $(P<0.05)$ values for both $E$ groups compared to $C$ group. A significant $(P<0.05)$ increase of $M n$ concentration in liver was noticed in group E2. No significant differences $(P>0.05)$ between groups were observed for $\mathrm{Mn}$ and Fe concentration in egg yolk.
\end{abstract}

Key words: manganese, iron, organometallic chelates, inulin, laying hens

\section{INTRODUCTION}

Nowadays, livestock is generally fed highly concentrated diets that are formulated to provide an excess of nutrients to maximize performance (Leeson et al., 2003). Traditionally, trace minerals are supplemented in the form of inorganic salts, such as sulphates, oxides and carbonates, to provide levels of minerals that prevent clinical de- ficiencies and allow the bird to reach its genetic growth potential (Bao et al., 2007). These amounts may be 3-4 times higher than animal requirement (Untea et al., 2011). When trace minerals are fed in excess of animal requirements, more is excreted as waste because of homeostatic mechanisms that serve to regulate tissue 
concentration of minerals (Spears et al., 1996).

Organic sources of minerals (organometallic chelates) have been used in order to enhance trace mineral bioavailability by binding minerals to organic molecules, allowing the formation of structures with unique characteristics (Liotta et al., 2009). Also, the use of organic sources of minerals in premixes may be a solution to solve the inadequate mineral intake or the presence of antagonists in the diet, which interfere with or unbalance mineral uptake (Nollet L. et al., 2007). Organometallic chelates may be added at a lower concentration in the diet than inorganic salts of trace minerals, without causing any negative effect on production performance and potentially reducing mineral excretion (El-Husseiny, 2012).

Inulin is a natural carbohydrate which acts within the digestive tract of monogastric animals (Breves et al., 2001), favoring the absorption of trace elements (Rumessen et al., 1990; Lopez et al., 2000). Few studies evaluated the effect of inulin as supplement on absorption of trace elements in monogastric animals (Chen and Chen, 2004; Yasuda et al., 2006). In experiments on rats, higher copper absorption in the presence of inulin in the diet has been reported (Coudray et al., 2006). Some authors reported that dietary inulin increases relative biological availability of dietary copper in weaned piglets, without effects on zinc and manganese (Untea et al., 2013). Inulin has been shown to increase the absorption of several minerals (calcium, magnesium, in some cases phosphorus) and trace elements (copper, iron, zinc), but the studies are relatively scarce and contradictory results were obtained in experiments on rats (ScholzAhrens and Schrezenmeir, 2007).

The Jerusalem artichoke (Helianthus tuberosus), plant with significant inulin content also known as the sunchoke, sunroot, topinambur or earth apple, is considered during other experimental trials on laying hens as prebiotic and possible substitute for antibiotic growth promoters (Poeikhampha and Bunchasak, 2010). Also, improvements of performances, feed utili- zation and egg production were observed when Jerusalem artichoke was included in poultry diets (Yildiz et al., 2008). Chicory (Cichorium intybus) root has a high content of fructooligosaccharides and inulin, which can be used to manipulate the composition of microflora in the gut and enhance its integrity (Flickinger et al., 2003).

This study presents the results obtained in an experiment conducted on laying hens, where the objective was to evaluate the effects of diet supplementation with amino acid chelated minerals $\mathrm{Fe}$ and $\mathrm{Mn}$ and inulin on absorption coefficients of these minerals and their content in egg and tissue.

\section{MATERIAL AND METHODS}

The present study was carried out at the National Research and Development Institute for Animal Biology and Nutrition, Balotesti, Romania, and the chemical analyses were carried out at the institute's laboratories. The experiment was conducted on 90 Lohmann Brown laying hens in the period from 46-52 weeks of age, divided into 3 groups (C, E1 and E2) with 30 hens/group and 3 hens/cage. Diet formulation considered the nutritional requirements of laying hens (NRC, 1994) and the basic diet was identical for all groups. A light regimen of 16 hours/day was applied during the trial period. Food and water were provided ad libitum. Two sources of inulin were used: first was a product based on a chicory root extract and the second source originated from Jerusalem artichoke powder, a plant which contains minerals, vitamins, proteins, dietary fiber, and inulin (Danilevičs, 2006).

The hens from control group (C) received a diet based on corn, rice bran and soybean meal with $16 \%$ of crude protein, as well as $60 \mathrm{mg} \mathrm{Fe} / \mathrm{kg}$ and $71.9 \mathrm{mg} \mathrm{Mn} / \mathrm{kg}$ of diet in form of inorganic salts. The formulations of the experimental diets (E1 and E2) differed from the control (C) group diet by the replacement of the inorganic salts of Fe (PRECHEZA, Czech Republic) and Mn (ERACHEM COMILOG, Belgium) by organometallic chelates of these elements (manganese chelate of glycine hydrate - EcoTrace ${ }^{\circledR} \mathrm{Mn} 20 \%$ and ferrous 
chelate of glycine hydrate - EcoTrace $® \mathrm{Fe}$ $20 \%$, Biochem, Germany ), at a level of $25 \%$ lower than in the premix for group C. Group E1 also included $0.5 \%$ of dry Jerusalem artichoke (S.C. Hofigal S.A., Romania), while group E2 included $0.5 \%$ of a product based on a chicory root extract (Frutafit@IQ, Sensus, Holland).

According to experimental protocol approved by the Ethical Committee of the $\mathrm{Na}$ tional Research-Development Institute for Animal Nutrition and Biology, Balotesti, Romania, two periods (five days each) of mineral balance were performed in the fourth and the sixth week as suggested by Khan et al. (2003). During balance periods, the feed, unconsumed feed and faeces samples were collected (10 samples/group/balance period) and prepared for determination of $\mathrm{Fe}$ and $\mathrm{Mn}$ using microwave digestion procedure described by Untea et al. (2012) and applying flame atomic absorption spectrophotometry (FAAS). The used equipment was an atomic absorption spectrometer Thermo Electron - SOLAAR M6 Dual Zeeman Comfort (Cambridge, UK), with deuterium lamp for background correction and airacetylene flame. Absorption coefficients of $\mathrm{Mn}$ and $\mathrm{Fe}$ were calculated based on their determination in ingested and excreted samples, supported by daily recordings of feed consumption and excreta quantity. Absorption coefficient (\%) represents the ratio: (absorbed mineral quantity / ingested mineral quantity) ${ }^{*} 100$, where the absorbed quantity represents the difference between the ingested amount and the excreted amount. The data for mineral balance in this study are presented as means of the values obtained in the two balance periods.

In the final week of the experiment, 18 eggs per group were randomly collected and 6 composite samples/group (3 eggs/sample) of egg yolk was prepared for $\mathrm{Fe}$ and $\mathrm{Mn}$ concentration determination by FAAS, according to the procedure of Untea et al. (2012).

At the end of the experiment, blood samples were collected from brachial vein of 6 hens from each group to determine haemoglobin (HGB) and haematocrit (HCT) content. The analysis was conducted using MINDRAY BC 2800 VET, AUTO HEMATOLOGY ANALYZER (Guangzhou, China). Also at the end of the experiment, 6 hens from each group were slaughtered according to the pro-visions of the Law on animal protection and welfare (Council Directive 93/119/CEE, 1993). Blood serum and liver samples were collected and prepared for determination of $\mathrm{Fe}$ and $\mathrm{Mn}$ concentration by FAAS using procedure described by Untea et al. (2012).

The data were analyzed using the StatView for MS Windows 5.0 software (SAS Institute Inc., Cary, NC, USA).

\section{RESULTS AND DISCUSSION}

The results of haemoglobin (HGB), haematocrit $(\mathrm{HCT}), \mathrm{Fe}$ and $\mathrm{Mn}$ content in blood serum are presented in Table 1.

No significant differences $(P>0.05)$ between groups concerning HGB and HCT content were registered (Table 1). Same was observed for $\mathrm{Fe}$ and $\mathrm{Mn}$ blood serum values.

Table1.

Results of blood serum analysis

\begin{tabular}{ccccc}
\hline & HGB $(\mathbf{g} / \mathbf{d L})$ & HCT $(\%)$ & Fe $(\boldsymbol{\mu g} / \mathbf{d L})$ & Mn $(\mathbf{n g} / \mathbf{m L})$ \\
\hline C & $7.83 \pm 1.22^{\mathrm{a}}$ & $24.20 \pm 1.92^{\mathrm{a}}$ & $405.29 \pm 41.84^{\mathrm{a}}$ & $103.20 \pm 12.87^{\mathrm{a}}$ \\
E1 & $8.05 \pm 0.55^{\mathrm{a}}$ & $24.83 \pm 2.64^{\mathrm{a}}$ & $394.90 \pm 25.42^{\mathrm{a}}$ & $104.57 \pm 16.37^{\mathrm{a}}$ \\
E2 & $7.96 \pm 0.90^{\mathrm{a}}$ & $23.60 \pm 1.52^{\mathrm{a}}$ & $404.32 \pm 64.06^{\mathrm{a}}$ & $97.80 \pm 8.84^{\mathrm{a}}$
\end{tabular}

Results are expressed as a mean \pm SD

Means with the same superscript in the same column are not statistically different $(P>0.05)$

HGB - haemoglobin

HCT - haematocrit 
Table 2.

Balance parameters for manganese and iron

\begin{tabular}{ccccc}
\hline & Balance parameters & Control & E1 & E2 \\
\hline \multirow{3}{*}{ Manganese } & Ingested (g/hen/day) & $22.90 \pm 2.18^{\mathrm{a}}$ & $15.97 \pm 2.74^{\mathrm{b}}$ & $16.25 \pm 5.02^{\mathrm{b}}$ \\
& Excreted (g/hen/day) & $18.22 \pm 3.21^{\mathrm{a}}$ & $12.30 \pm 3.02^{\mathrm{b}}$ & $11.52 \pm 2.94^{\mathrm{b}}$ \\
& Absorption coefficient (\%) & $20.43 \pm 3.03^{\mathrm{a}}$ & $22.97 \pm 4.33^{\mathrm{a}}$ & $29.10 \pm 6.2^{\mathrm{b}}$ \\
\cline { 3 - 4 } Iron & Ingested (g/hen/day) & $36.07 \pm 5.27^{\mathrm{a}}$ & $28.71 \pm 6.41^{\mathrm{b}}$ & $28.58 \pm 6.01^{\mathrm{b}}$ \\
& Excreted (g/hen/day) & $26.62 \pm 6.07^{\mathrm{a}}$ & $24.94 \pm 5.21^{\mathrm{a}}$ & $25.09 \pm 7.13^{\mathrm{a}}$ \\
& Absorption coefficient (\%) & $26.22 \pm 4.82^{\mathrm{a}}$ & $13.15 \pm 5.42^{\mathrm{b}}$ & $12.22 \pm 6.02^{\mathrm{b}}$ \\
\hline
\end{tabular}

Results are expressed as a mean \pm SD

Means with the different superscript in the same row are statistically different $(P<0.05)$

Table 3.

Manganese and iron concentration in liver

\begin{tabular}{|c|c|c|}
\hline Group & $\begin{array}{c}\text { Manganese } \\
\text { ppm }\end{array}$ & $\begin{array}{l}\text { Iron } \\
\text { ppm } \\
\end{array}$ \\
\hline $\begin{array}{l}\text { C } \\
\text { E1 } \\
\text { E2 }\end{array}$ & $\begin{array}{l}7.40 \pm 0.55^{\mathrm{a}} \\
7.75 \pm 0.51^{\mathrm{a}} \\
8.66 \pm 0.49^{\mathrm{b}}\end{array}$ & $\begin{array}{l}250.70 \pm 15.10^{a} \\
247.24 \pm 16.46^{a} \\
240.65 \pm 11.12^{a}\end{array}$ \\
\hline
\end{tabular}

Results are expressed as a mean \pm SD

Means with the different superscript in the same column are statistically different $(P<0.05)$

Table 4.

Manganese and iron concentration in egg yolk

\begin{tabular}{ccc}
\hline Group & $\begin{array}{c}\text { Manganese } \\
\text { ppm }\end{array}$ & Iron \\
& $2.12 \pm 0.22^{\mathrm{a}}$ & Ppm \\
\hline C & $1.99 \pm 0.23^{\mathrm{a}}$ & $139.22 \pm 15.10^{\mathrm{a}}$ \\
E2 & $2.01 \pm 0.07^{\mathrm{a}}$ & $140.21 \pm 6.46^{\mathrm{a}}$ \\
E2 & & $141.63 \pm 11.12^{\mathrm{a}}$ \\
\hline
\end{tabular}

Results are expressed as a mean \pm SD

Means with the same superscript in the same column are not statistically different $(P>0.05)$

The results of mineral balance calculation are presented in Table 2. A significantly lower $(\mathrm{P}<0.05)$ quantity of ingested $\mathrm{Fe}$ and its absorption coefficients was noticed in $E$ groups. It was not the case for Mn, where the $25 \%$ reduction of its organic source in the diets, did not produce a reduction of absorption coefficients in $E$ groups compared to group C. Therefore, it can be assumed that the manganese absorption was influenced by inulin supplements added into diets of experimental groups. The obtained results sustain the reports in the literature with regard to antagonistic interactions between Fe and Mn (Creech, 2004).

Although the $\mathrm{Mn}$ concentration was lower in experimental diets, the liver concentration of $\mathrm{Mn}$ was significantly higher $(P<0.05)$ for E2 group than for group $C$. These results confirm the observation concerning the high value of $\mathrm{Mn} \mathrm{ab}$ sorption coefficient for E2 group.

Iron-manganese antagonism was also noticed at the level of the main mineral depo- sition organ - the liver (Table 3), where Fe concentration was lower for $\mathrm{E}$ groups compared to group $\mathrm{C}$, but this concentration decrease was not statistically significant $(P>0.05)$.

Manganese and iron egg yolk concentrations, registered at the end of the experiment, are presented in Table 4. There were no significant differences $(P>0.05)$ concerning the content of $\mathrm{Mn}$ and $\mathrm{Fe}$ in egg yolk. The obtained results are in the range of values reported in the literature for $\mathrm{Fe}$ and $\mathrm{Mn}$ concentration in egg yolk (Skrivan, 2005; Orda, 2012).

\section{CONCLUSIONS}

Lowering the amount of organic sources of manganese and iron in laying hens diets by $25 \%$ led to lower absorption coefficients of $\mathrm{Fe}$. On the contrary, the presence of inulin supplements, associated with Fe-Mn antagonism, improved the absorption coefficients of $\mathrm{Mn}$. The decreased content of $\mathrm{Fe}$ and $\mathrm{Mn}$ in diets for laying hens, in conjunction with inulin supplementation, did 
not produce any adverse effects on Fe and $\mathrm{Mn}$ concentration in egg yolk.

Further studies are required in order to investigate interactions between minerals such as $\mathrm{Fe}$ and $\mathrm{Mn}$, as well as their absorption, metabolism and excretion, using their organic and inorganic forms at different levels of inclusion rate in laying hens diets supplemented with inulin sources.

\section{ACKNOWLEDGEMENTS}

This paper was published under the frame of European Social Found, Human Resources Development Programme 20072013, project no. POSDRU/159/1.5/S/132765.

\section{REFERENCES}

1. Khan, M. A., Mahr-Un-Nisa, S. M., Sarwar, M. (2003). Techniques Measuring Digestibility for the Nutritional Evaluation of Feeds. International Journal of Agriculture and Biology, 5 (1), 91-94.

2. Bao, Y. M., Choct, M., Iji, P.A. and Bruerton, K. (2007). Effect of organically complexed copper, iron, manganese and zinc on broiler performance, mineral excretion and accumulation in tissues. Journal of Applied Poultry Research, 16 (3), 448-455.

3. Breves, G., Szentkuti, L., Schröder, B., (2001). Effects of oligosaccharides on functional parameters of the intestinal tract of growing pigs. Deutsche Tierarztliche Wochenschrift, 108 (6), 246-248.

4. Chen, Y. C., Chen, T. C. (2004). Mineral utilization in layers as influenced by dietary oligofructose and inulin. International Journal of Poultry Science, 3 (7), 442-445.

5. Creech, B. L., Spears J. W., Flowers, W. L., Hill, G. M., Lloyd, K. E., Armstrong, T. A., Engle, T. E. (2004). Effect of dietary trace mineral concentration and source (inorganic vs. chelated) on performance, mineral status, and fecal mineral excretion in pigs from weaning through finishing. Journal of Animal Science, 82 (7), 2140-2147.

6. Council Directive $93 / 119 /$ CEE on the protection of animals at the time of slaughter or killing, (OJ No. L340, 31.12.1993, p. 21) amended by (EC) No 806/2003 (OJ No. L122, 16.05.2003, p.1).

7. Coudray, C., Coudray, C. F., Gueux, E., Mazur, A., Rayssinguier, Y., (2006). Dietary inulin intake and age can affect intestinal absorption of zinc and copper in rats. Journal of Nutrition, 136 (1), 117-122.

8. Danilevičs, A., Beķers, M., Linde, R. (2006). Wasteless technology for topinambour concentrate production. Proceedings of the international conference "EcoBalt", Riga, p. 98-99.

9. El-Husseiny, O. M., Hashish, S. M., Ali R. A., Arafa, S. A., Abd El-Samee, L. D., Olemy , A. A. (2012). Effects of Feeding Organic Zinc,
Manganese and Copper on Broiler Growth, Carcass Characteristics, Bone Quality and Mineral Content in Bone, Liver and Excreta. International Journal of Poultry Science, 11 (6), 368-377.

10. Flickinger, E. A., Vanloo, J., Fahey, G. C. (2003). Nutritional responses to the presence of inulin and oligofructose in the diets of domesticated animals: a review. Critical Review in Food Science and Nutrition, 43 (1), 19-60.

11. Leeson, S. (2003). A new look at trace mineral nutrition of poultry: Can we reduce the environmental burden of poultry manure? In Nutritional Biotechnology in the Feed and Food Industries: Proceedings of Alltech's $19^{\text {th }}$ Annual Symposium. Eds. T. P. Lyons, K. A. Jacques, Nottingham University Press, Nottingham, UK.

12. Liotta, L., Chiofalo, V., D'Alessandro, E., Macrì, F., Caristina, G., Chiofalo, B. (2009) Use of organometallic chelates in broiler diet: effect on the performance and bone structure. Preliminary results. Italian Journal of Animal Science, 8 (Suppl. 2), 763-765.

13. Lopez, H. W., Coudray, C., Levrat-Verny, M. A., Feillet-Coudray, C., Demigne, C., Remesy, C., (2000). Fructooligosaccharides enhance mineral apparent absorption and counteract the deleterious effects of phytic acid on mineral homeostasis in rats. Journal of Nutritional Biochemistry, 11 (10), 500-508.

14. NRC - National Research Council (1994). Nutrient Requirements of Chickens. $9^{\text {th }}$ revised edition. The National Academies Press, Washington, DC.

15. Nollet, L., van der Klis, J. D., Lensing, M., Spring, P. (2007). The Effect of Replacing Inorganic With Organic Trace Minerals in Broiler Diets on Productive Performance and Mineral Excretion. Journal of Applied Poultry Research, 16, 592-597

16. Orda, J., Jamroz, D., Wiliczkiewicz, A., Skorupińska, J. Kubizna, J. K. (2012). The influence of porcine blood by-products on laying hen performance, egg quality, and yolk mineral content. Journal of Animal and Feed Sciences, 21 (1), 107-121

17. Poeikhampha, T., Bunchasak, C. (2010). Effect of sodium gluconate on $\mathrm{pH}$ value, ammonia and short chain fatty acids concentration in batch culture of porcine cecal digesta. Journal of Applied Sciences, 10, 1471-1475.

18. Rumessen, J. J., Bodé, S., Hamberg, O., Gudmand-Hoyer, E. (1990). Fructans of Jerusalem artichokes: intestinal transport, absorption, fermentation and influence on blood glucose, insulin and C-peptide responses in healthy subjects. The American Journal of Clinical Nutrition, 52 (4), 675-681.

19. Scholz-Ahrens, K., Schrezenmeir, J. (2007). Inulin and oligofructose and mineral metabolism: the evidence from animal trials. The Journal of Nutrition, 137 (11), 2513S-2523S.

20. Skrivan, M., Skrivanova, V., Marounek, M. (2005). Effects of dietary zinc, iron and cooper in layer feed on distribution of these elements in eggs, liver, excreta, soil, and herbage. Poultry Science, 84 (10), 1570-1575. 
21. Spears, J. W. (1996). Optimizing mineral levels and sources for farm animals. In Nutrient Management of Food Animals to Enhance and Protect the Environment. Ed. E. T. Kornegay, CRC Press, Boca Raton, FL.

22. Untea, A. E., Olteanu, M., Maros, I., Criste, R. D. (2011). Decrease of $\mathrm{Cu}$ and Fe concentrations from broiler droppings using dietary organometallic compounds. Biotechnology in Animal Husbandry 27 (3), 759-768.

23. Untea, A., Criste, R. C., Vladescu, L. (2012). Development and validation of a microwave digestion - FAAS procedure for $\mathrm{Cu}, \mathrm{Mn}$ and $\mathrm{Zn}$ determination in liver. Revista de Chimie, 63 (4), 341- 346.

24. Untea, A. E., Criste, R. D., Taranu, I., Souffrant,
W., Janczyk, P., Vladescu, L., Dragomir, C. (2013). Availability of microelements in recently weaned piglets fed diet supplemented with inulin. Czech Journal of Animal Science, 58 (8), 369-374.

25. Yasuda, K., Roneker, K. R., Miller, D.D., Welch, R.M., Lei, X.G., (2006). Supplemental dietary inulin affects the bioavailability of iron in corn and soybean meal to young pigs. The Journal of Nutrition, 136 (12), 3033-3038.

26. Yildiz, G., Sacakli, P., Gungor, T. Uysal, H., (2008). The effect of Jerusalem artichoke (Helianthus tuberosus L.) on blood parameters, liver enzymes and intestinal $\mathrm{pH}$ in laying hens. Journal of Animal and Veterinary Advances, 7 (10), 1297-1300.

\title{
УТИЦАЈ ОРГАНОМЕТАЛНИХ ХЕЛАТА И ИНУЛИНА У ХРАНИ ЗА КОКЕ НОСИЉЕ НА АПСОРПЦИОНЕ КОЕФИЦИЈЕНТЕ МАНГАНА И ГВОЖЪА И ЊИХОВ САДРЖАЈ У ЈАЈИМА И ТКИВУ
}

\author{
Gabriela Maria Cornescu ${ }^{1}$, Tatiana Dumitra Panaite ${ }^{2}$, Arabela Elena Untea ${ }^{2}$, Anca Bercaru ${ }^{2}$, Horia \\ Grosu $^{1}$ \\ ${ }^{1}$ Faculty of Animal Husbandry, University of Agricultural Sciences and Veterinary Medicine, 59 \\ Marasesti Boulevard, 011464 Bucuresti, Romania \\ ${ }^{2}$ National Institute of Research and Development for Animal Biology and Nutrition, 1 Calea Bucuresti, \\ 077015, Balotesti, Ilfov, Romania
}

Сажетак: Циљ овог истраживања био је да се испита утицај органских извора мангана и гвожђа, као и инулина у храни за коке носиље на апсорпцију ових елемената и њихово депоновање у јајима и ткиву. Истраживање је спроведено на 90 Lohmann Brown кока носиља у периоду од 46-52 недеље старости, које су подељене у 3 групе са 30 кока/групи и 3 коке/кавезу. Коке из контролне групе (К) су добијале храну базирану на кукурузу, пиринчаним мекињама и сојиној сачми, са 16\% сирових протеина и додатком 60 мг/кг Фе и 71,9 мг/кг Mn у облику неорганских соли. У храни експерименталних група (Е1 и Е2), неорганске соли $\mathrm{Fe}$ и $\mathrm{Mn}$ су замењене органометалним хелатима ових елемената, и то тако да је њихов садржај био $25 \%$ нижи него садржај неорганских соли ових елемената у премиксу контролне групе. Као извор инулина, у храну групе E1 је додато 0,5\% јерусалимске артичоке, док је храна групе E2 садржавала $0,5 \%$ производа базираног на екстракту корена цикорије. На крају огледа, 6 кока носиља из сваке групе је жртвовано и у узорцима крвног серума и јетре су одређене концентрације Fe и Mn. Такође, на крају огледа је одређена концентрација Fe и Mn у жуманцу јаја из све три групе. Концентрације мерених параметара крвног серума (хемоглобин, хематокрит, Fe и $\mathrm{Mn}$ ) су биле ниже у експерименталним (Е) групама него у К групи, али те разлике нису биле статистички значајне $(P>0,05)$. Апсорпциони коефицијенти мангана су били већи у $E$ групама у односу на контролну групу, са значајним повећањем $(P<0,05)$ у групи $E 2$. Апсорпциони коефицијенти гвожђа су били значајно нижи $(P<0,05)$ у $E$ групама у односу на групу К. Регистрована је значајно већа концентрација $(P<0,05)$ Mn у узорцима јетре из групе E2. Између група није установљена значајна разлика $(P>0,05)$ концентрације $\mathrm{Fe}$ и $\mathrm{Mn}$ у жуманцу jaja.

Кључне речи: манган, гвожђе, органометални хелати, инулин, коке носиље

Received: 21 November 2014 